\title{
PSYCHE
}

VOL. XXI.

APRIL, 1914.

No. 2

\section{THE NORTH AMERICAN FAMILIES OF LEPIDOPTERA.}

\author{
By Wm. T. M. Forbes, \\ Worcester, Mass.
}

The following is an attempt to present in tabular form the differences in the families of Lepidoptera which occur in the United States, to which the few well characterized Central American families of Macros have been added for completeness. None of the accepted lists have been followed strictly in family delimitation. but on the other hand none of the changes is new. The butterflies are according to the system followed by Scudder and Comstock; the Macro-heterocera follow Dyar's list with a couple of changes; the Tineids are separated along the lines laid down in various papers by Busck, with the addition of the primitive families recognized by Spuler in the European fauna.

As compared with Dyar's list the principal changes are the following:

The Parnassiidæ are combined with the Papilionidæ.

The Agapetidæ, Heliconidæ, Ithomyidæ, Lymnadidæ, Libytheidæ, and Nymphalidæ are combined as Nymphalidæ.

The Megathy midæ with the Hesperiidæ.

The Nycteolidæ with the Noctuidæ, following Hampson. I am not at all sure that the union is justified, but no satisfactory family characters have been developed, and a number of the genera are doubtful. The most distinct characters of the Nycteolidæ are the slender male frenulum-hook, the peculiarly enlarged and bent basal joint of the antenna, the head-vestiture, and the raised scaling. The last is shared by various Noctuids, and intergrades seem to occur in the case of the other characters. The peculiar wing-form, which seems to have first given Nycteola its family status, is not shared by our second species, Characoma nilotica $(=N$. proteella). 
Apatelodes is transferred to the mainly tropical family Eupterotidæ, on both larval and adult characters, but it makes a very distinct subfamily, largely developed in South America. So far as I can see the Australia Chelepteryx will also belong to it, and probably other Australian genera. It seems to be one of the interesting types, like the marsupials, which have survived only in America and Australia.

Psychophora fasciata is a normal Noctuid, with large ocelli and typical trifid Noctuid venation; on the other hand, so far as I can see, Curtis' figures of $P$. sabinii represent the common arctic Hydriomenid geometer which Hulst considered it to be.

The Pyromorphidæ and Chalcosiidæ have been treated as subfamilies of the typically European family Zygænidæ. Acoloithus, of our species, might about as well be placed in the typical Zygæninæ, next to Ino, as among the Pyromorphinæ.

The following partial generic list will explain the disposition of the Tineina:

$\quad$ Yponomeutida
Simæthis
Choreutis
Allononyma
Setiostoma
Glyphipteryx
Atteva (CEta)
Yponomeuta
Plutella
Cerostoma
Trachoma
Scythris?
Argyresthia?
Zelleria?
Epermenia?
Schreckensteinia?
Gelechiid
as in Dyar's list
EEcophorid
as in Dyar's list
also Eido
Endrosis
but not Ethmia
Ethmiidø
Ethmia

$\quad$ Stenomatida
Stenoma
Ide
Brachiloma
$\quad$ Blastobasida
as in Dyar's list
exc. Endrosis
$\quad$ Cosmopterygida
Coleophora?
Batrachedra?
Cosmopteryx
Lymnæcia
Stilbosis
Mompha (Laverna)
Walshia
Theisoa (Cacelice)
Chrysopeleia
Psacaphora
Leucophryne
Erineda?
$\quad$ Elachistida
Elachista
Heliozelide
Heliozela
Antispila

Cycloplasis ?

Coptodisca?

Douglasia?

Tinagma?

Heliodinida

Heliodines

Acrolepiidae

Acrolepia

Gracilariidas

Chilocampyla

Acrocercops

Parectopa

Gracilaria

Lithocolletis

Cremastobombycia

Ornix

Leucanthiza

Marmara

Lyonetiidae

Bedellia?

Proleucoptera

Philonome

Lyonetia

Phyllocnistis

Bucculatrix ? 
Tineida

Argyresthia ?

Zelleria?

Monopis

Tinea

Trichophaga

Tineola

Scardia

Xylesthia

Amydria

Setomorpha

Anaphora
Acrolophus

Hypoclopus

Pseudanaphora

Tischeriida

Tischeria

Coptotriche

Opostegida

Opostega

Nepticulidoe

Nepticula

Ectœedemia

Trifurcula
Adelida

Incurvaria

Brackenridgia

Cyane?

Isocorypha?

Graya ?

Nemotois

Adela

Prodoxida

Prodoxus

Pronuba

I acknowledge considerable help from Mr. Busck in this part of the table, and regret he was unable to take time to contribute the Tineina as a whole. The interrogation points indicate some of the principal points where the family positions are uncertain, either from lack of study of dissections, or from failure to develop characters of true family rank. Most of the genera $I$ have not seen I have simply omitted from the list, unless their position was quite evident. The Heliozelidæ, as they stand here are heterogeneous, with little doubt. Part of the genera may be distributed among the recognized families, while some may need to become typical of new ones. There are indications of a connection between Tischeria, Opostega and this group, through such forms as the Old-world genus Opogona, which may or may not be significant. Opostega is certainly aculeate, Tischeria has structures corresponding to aculeæ, but so enlarged and modified that their status is doubtful, while I am unable to see any at all in Antispila. The whole range of structure in the five families Gelechiidæ to Blastobasidæ is hardly as significant as that within the Tineidæ, even as here restricted.

The principal difference from the arrangement in Comstock's Manual is the treatment of the Tortricina, Geometrina and Pyralidina; (except the feathered forms) each as a single family. His Cymatophoridæ is the Thyatiridæ of this table, and his Zygænidæ are here called Syntomidæ, following general European usage in treating Zygæna as the group related to Pyromorpha. The Auzatidæ have been combined with the Drepanidæ (Platypterygidæ).

Kirby's Bibliography is so different in its treatment of family 
lines that a detailed comparison is not worth while; for instance his Lasiocampidæ are here divided among the Saturniidæ, Lonomiidæ, Eupterotidæ, Lasiocampidæ, and Megalopygidæ, members of most of which also occur in others of his families.

The characters used are in general familiar, and fully explained, for instance, in Smith's Glossary of Entomology, but the following points may not be clear. The "quadrifid" venation is that in which $\mathbf{M}_{2}$ and $\mathbf{M}_{3}$ are so closely associated with the stem of cubitus as to appear more or less dislocated branches of it, as well as the two true branches of cubitus; in the trifid venation only $\mathbf{M}_{3}$ is associated with cubitus, and $\mathbf{M}_{2}$ is free, associated with the radial stem, or lost; of course in primitive forms, where the medials keep their basal connection direct, the cubitus has only the two branches that properly belong to it.

When only one pair of palpi are developed they are the labial; but in a few primitive forms, such as Prodoxus, the maxillary palpi are the larger and more conspicuous - they can be easily distinguished by their attachment to the tongue, and in these primitive forms by their larger number of joints (5) and free movability, being folded near the middle in repose, and usually in dead material.

Aculex are minute spinules scattered over the wing-membrane. They are several times as numerous as the scales, but so small as only to be visible with higher powers of the microscope, and being covered by the scales can only be seen in bleached and stained or denuded wings. In the Micropterygidæ, Hepialidæ, Prodoxidæ, Adelidæ and Nepticulidæ they are generally distributed; in the Heliozelidæ, Tischeriidæ and Opostegidæ they are mostly in the region of the base of the cell of the fore wing, and somewhat difficult to find; while in all the other Lepidoptera they are absent, except for a patch of enlarged modified ones near the base of the inner edge of the fore wing.

The antennæ in the great majority of Lepidoptera have regularly imbricated scales on the upper side of the shaft, while the sides, pectinations when present, and under side are covered only with minute sensory hairs. In the lowest families, however, such as the Tineidæ, the whole surface is scaled, and on the other hand the Saturniidæ have lost all the scales except on the basal joint. 
At the base of the abdomen, on each side, there is a large cavity, which, to judge by its position and gross structure, is probably auditory in function. This is called the tympanic cavity here, and its outlet, which lies at the boundary between thorax and abdomen, the tympanic opening. Usually it is high up, about on the level of the wings in a spread specimen, but in the Geometridæ it is lower, and generally very conspicuous. In the Pericopidæ, where it is also particularly large, it is as high as in most families, and projects slightly above the general surface of the abdomen.

In counting the number of anals in the fore wing (alternative No. 8) an imperfect and rudimentary first anal, which only forms a short bar near the margin, is often met; in the Macros (forms with the wing-membrane three or four times as wide as its fringe or more, and generally hairy or deep vestiture) such a rudiment is not counted; in the Micros (where the wing-membrane is not more than twice as wide as its fringe, and the vestiture, except on the head, is scaly) it is. Doubtful cases have generally been entered twice in the table, but no attempt has been made to make the part referring to the Tineina complete.

Table of Families. ${ }^{1}$

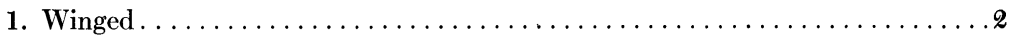

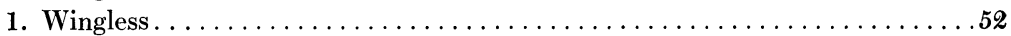

2. Hind wings with four or five radials, with at least ten veins besides anals, wing-

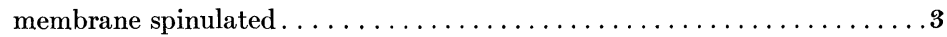

2. Hind wings with only one free radial (two in the otherwise much reduced Douglasia group); with at most six (or with Sc, 7) veins from cell . . . . . . . 4

3. Wings hardly wider than their fringe, expanse about one-half inch

MicRopterygid 2

3. Wings ample, fringe narrow, expanse over one inch......... HePIALId

4. Each wing deeply cleft into six narrow strips............ ORNEODID $A$

4. Fore wing moderately cleft into two, and hind wing deeply into three feathers

Pterophorides

4. Wings entire, or fore wing only, moderately cleft...............

5. Inner margin of fore wing and costal margin of hind wing narrowly folded, and interlocking; fore wing at least four times as long as wide, and base, at least, of hind wing transparent.............................

5. Wings not interlocking at middle of margin, very rarely transparent, and if

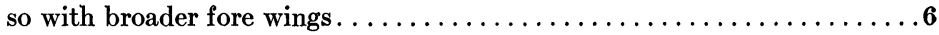

1 The New England families are indicated by small capitals. 
6. Hind wing lanceolate, without marked anal angle, or notched below apex and trapezoidal; the fringe almost as wide as wing, or wider. . Tineina in part 55

6. Hind wings much broader than their fringe, never lanceolate and rarely trapezoidal with produced apex........................

7. A double series of enlarged and divergent scales along $\mathrm{Cu}$ of hind wing below Pterophorida (Agdistince)

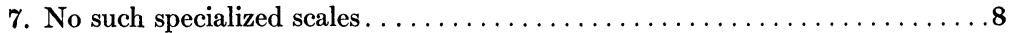

8. Fore wing with two anals at margin .......................

8. Fore wing with only one anal reaching margin, 1st A rudimentary, or represented by a fold; $3 \mathrm{~d}$ A at most by a short spur ............... 15

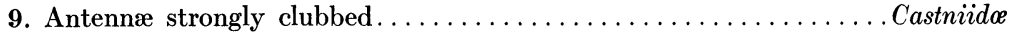

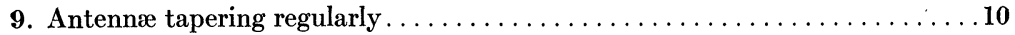

10. Sc and $\mathbf{R}$ of hind wing independent, parallel, connected by a strong cross-vein near middle of cell or beyond . . . . . . . . . . . . . . . . . . 11

10. Sc arising from cell near middle (sometimes free also for a short distance near

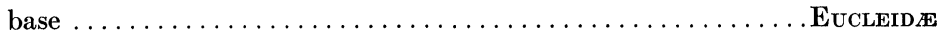

10. Sc arising near tip of cell. ...........................

10. Sc arising separate from $R$, running closely parallel to it to well beyond end of cell, or fused with it beyond end of cell; the base of $\mathbf{R}$ in that case either complete, showing as a short spur, or lost............ PyraLIDID

10. Sc. entirely independent of $R$, or connected by a weak cross-vein, or one near base of wing, Sc and $\mathrm{R}$ sharply divergent before end of cell, Tineina in part 55

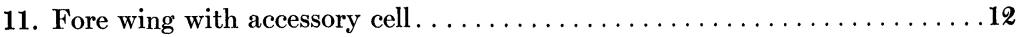

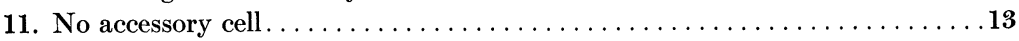

12. Wings lanceolate, strong; body heavy, far exceeding the hind wings when

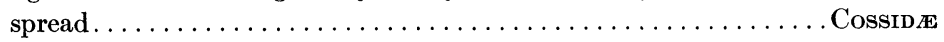

12. Wings ample, rounded, body short and slender............. Dalceridoe

13. Tongue developed, palpi scaled ................. Zygønido (Chalcosiin $x)$

13. Tongue absent, palpi small and hairy or absent........most Psychides (o's)

14. R 5 long-stalked, colors light, the northern species with crinkly hair on fore

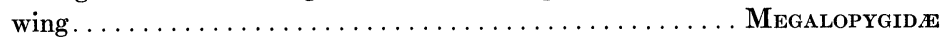

14. R 5 from cell, dark, smoothly scaled forms ...... ZYGANID E (PYROMORPhine)

15. Hind wing with three anals, the first often fading out toward base.......16

15. Hind wing with two anals or less, at most with a short spur of 1st A at margin

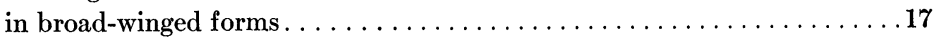

16. Sc and $\mathrm{R}$ of hind wing closely parallel or fused beyond end of cell

Prralidide in part

16. Sc and $\mathbf{R}$ strongly divergent from before end of cell...... Trnerna in part 55

17. Antennæ distinctly swollen toward tip, and frenulum wanting, (Butterflies) 18

17. Antennæ not swollen toward tip, or if so (Agaristidæ, Sphingidæ) with a strong frenulum . . . . . . . . . . . . . . . . . . . .

18. Fore wing with all veins present, from cell, eyes strongly lashed in front, antennæ separated at base by a distance greater than half width of eyes

HESPERIIDEF

18. Fore wing with some radials stalked or absent, eyes rarely lashed, antennæ

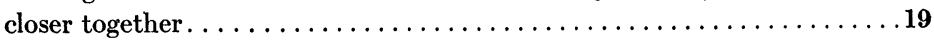

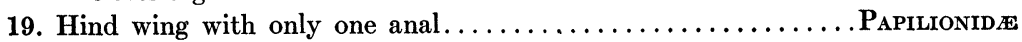


19. Hind wing with two well-developed anals. ..................20

20. $\mathbf{M}_{2}$ from middle of end of cell in both wings, or obsolete, fore wing in northern species with ten or eleven veins . . . . . . . . . . . . . . . . . 21

20. $M_{2}$ distinctly associated with radial stem, in one, and usually in both wings; lower discocellular vein often obsolete, with at least a trace of a humeral vein .......................................2

21. A humeral vein in hind wing................ Erycinido (Riodinido)

21. No humeral vein............................LYCANIDA

22. Butterfly walking on four legs (except female of Hypatus), radius five-branched,

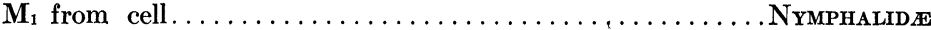

22. Butterfly using all its legs for walking, radius usually four-branched, $\mathbf{M}_{1}$ stalked

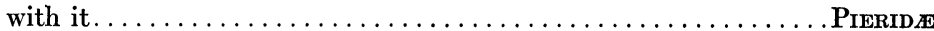

23. Our species very stout and two inches or more in expanse, the hind wings rarely reaching beyond middle of abdomen, $\mathrm{Sc}$ and $\mathrm{R}$ of hind wing connected at the middle of the cell or rather before by a vein $\left(\mathbf{R}_{1}\right)$ which is as strong as any; and then closely parallel to end of cell or beyond......... SpHINGIDs

23. Wings proportionately larger, $\mathrm{Sc}$ and $\mathrm{R}$ rarely connected by a strong cross vein, and if so, strongly divergent beyond it..................24

24. Sc and $\mathbf{R}$ separate, but connected by a more or less distinct cross-vein; accessory cell fused with discal cell, but with the line of separation $\left(\mathbf{R}_{4}+_{5}\right)$ indicated by a slight thickening, starting from an angulation in the stem of $R$; species under one inch in expanse.................... few Tineina 55

24. Accessory cell separated by a full-sized vein, or completely absent. . . . .25

25. $\mathrm{Cu}$ of fore wing apparently three-(in a couple of Lithosians two-) branched . 26

25. $\mathrm{Cu}$ of fore wing apparently four-branched ...................40

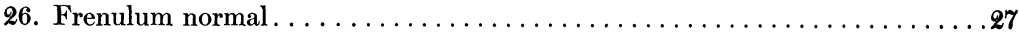

26. Frenulum rudimentary (less then one fifteenth length of hind wings) or absent 33

27. Sc and $\mathbf{R}$ fused from base of hind wing beyond middle, swollen at the base, then rapidly diverging; very slender............. LiтноsıID $\approx$ in part

27. Sc and $\mathrm{R}$ separate at extreme base, then closely approximate or fused a greater or less distance. . . . . . . . . . . . . . . . . . . . . . . . 28

27. Sc and R sharply divergent from close to base ..... . URANIID E (EPIPLEMINA)

28. Stout-bodied moths, the thorax at least a sixth as wide as length of fore wings

28. Slender moths. . . . . . . . . . . . . . . . . . . . . . . . . . . . 32

29. A strong brace vein from an angle near base of Sc to root of frenulum.

GeOMETRID жe in part

29. Sc moderately thickened and curved at base ................... 30

30. $\mathrm{Cu}$ apparently three-branched in hind wing. . . . . . . . . . . . . . . 31

30. $\mathrm{Cu}$ apparently four-branched in hind wing. .............. ThYaTIRID

31. Tongue wholly absent, the northern species with hyaline subterminal spots

Eupterotidae (APatelodinde)

31. Tongue distinct, usually strong; wings fully scaled . . . . . . . . Notodontid

32. Tympanic opening at base of abdomen small and subdorsal, 1st A usually partly present, Sc of hind wing slightly bent at base and but little enlarged; the humeral angle not expanded. Usually with $\mathbf{M}_{3}$ and $\mathrm{Cu}_{1}$ stalked in both wings. . 
32. Tympanic opening with a few exceptions conspicuous, lateral; 1st A wholly absent in both wings; Sc of hind wing sharply bent or much enlarged at base, almost always with a brace vein running across to base of frenulum most GeOMETRID

33. Sc and $\mathbf{R}$ of hind wing fused for a very short distance, then sharply divergent, separate from base, or connected by a weak cross-vein; tympanic opening inconspicuous...................................

33. Sc sharply divergent from $\mathbf{R}$ at extreme base, then sharply bent and touching, fusing or closely parallel to it or connected by a strong cross-vein; tympanic opening conspicuous, lateral.................. a few Geometrid

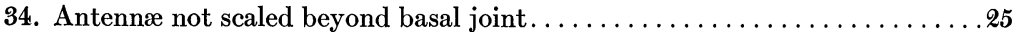

34. Antennæ closely scaled on upper side......................

35. Two anals; $\mathbf{M}_{1}$ of fore wing connate or stalked with radial stem, Ceratocampids

35. $M_{1}$ separate from radial stem; with only one anal, or upper discocellular vein

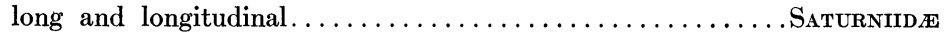

36. Sc of hind wing sharply divergent from $R$ from close to base..........37

36. Sc and $R$ parallel at base, connected by a weak cross-vein. . . . . . . . . 39

37. $\mathbf{R}_{4+5}$ widely separated from $\mathbf{R}_{3}$ all the way from cell to margin. . . LACOSOMIDA

87. $R_{4}$ and $R_{5}$ arising from cell closely associated with $R_{3} \ldots \ldots \ldots \ldots \ldots$

38. $\mathbf{R}_{5}$ and $\mathbf{M}_{1}$ stalked or closely approximate at base, and separate from $\mathbf{R}_{4}$ Uraniido (Uraniino)

38. $\mathbf{R}_{5}$ separate from $\mathbf{R}_{4}$, which may be stalked with $\mathbf{R}_{3} \ldots \ldots \ldots$ Lonomiidoe

39. Frenulum about one-sixteenth length of hind wing. . Eupterotidee (Eupterotino)

39. Frenulum obsolescent, not exceeding humeral angle, or absent... Bombycidae

40. $\mathrm{Cu}_{2}$ of fore wing arising from cell about a third way out from base, or even nearer base; $\mathbf{R}_{5}$ stalked with $\mathbf{M}_{1}$, with humeral veins in our species; no

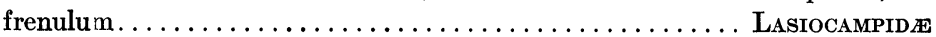

40. $\mathrm{Cu}_{2}$ of fore wing arising well beyond middle of cell; usually with frenulum. .41

41. Sc and $R$ of hind wing strong and parallel to beyond end of cell, and then approaching very close or fusing a short distance........... DREPANIDE

41. Sc and $R$ fusing before end of cell or wholly independent...........42

42. Fore wing with complete venation (twelve veins) all the radials, medials and cubitals arising separately, or with $\mathbf{R}_{2}$ and ${ }_{3}$ shortly stalked..... THYRIDIDE

42. $R_{3}$ and ${ }_{4}$ or $R_{4}$ and ${ }_{5}$ long-stalked or with some veins absent..........43

43. Sc apparently absent (fused except at extreme base with $\mathbf{R}$ )..... SynTomide

43. Sc and $R$ separating before end of cell.....................44

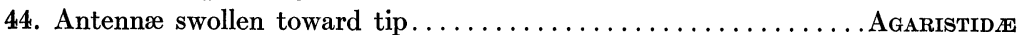

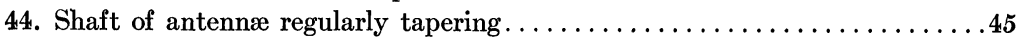

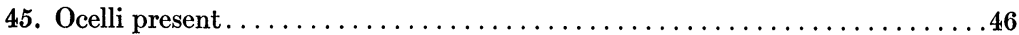

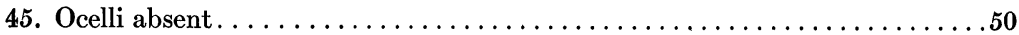

46. Sc and $R$ of hind wing fused to middle of cell or beyond..... most ARCTIID

46. Sc and $R$ fused for more than a fifth length of cell, but the fusion not reaching middle....................................47

46. Sc and $\mathbf{R}$ fused for less than a fifth length of cell, the fusion sometimes imperfect.......................................48

46. Sc and $R$ connected by a strong cross-vein......... a few Lymantriide*

* The Hypsidæ, distinguished by the well developed tongue, are represented by an unidentified and aberrant species in the Barnes Collection. 
47. Hind tarsus ordinarily not more than eight times as long as thick, often with reduced tibial spurs; $\mathbf{M}_{2}$ reduced only in Eubaphe; in the rest of full strength and associate with cubital stem; moths often stout; Sc very much swollen

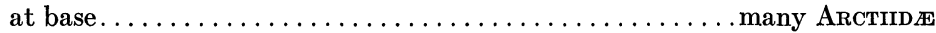

47. Hind tarsus ordinarily much more slender, the tibia with long spurs; $\mathbf{M}_{2}$ usually well separated from cubital stem, though nearer it than radial, and often weaker than the other veins; Sc not more than twice as thick as $\mathbf{R}$ in their basal portion; usually slender moths............... some NocTUID\&

48. Tympanic bullæ enlarged dorsally, showing from dorsal side as two rounded bosses on the first segment of the abdomen; brilliantly marked species

Pericopide

48. Tympanic bullæ inconspicuous. . . . . . . . . . . . . . . . . 49

49. White or yellow species with palpi not reaching the middle of the smoothscaled front, and four-branched $\mathrm{Cu}$ in both wings..... ARCTIID 2 (Haploa)

49. Species with longer palpi, three-branched $\mathrm{Cu}$ in hind wings or gray ground

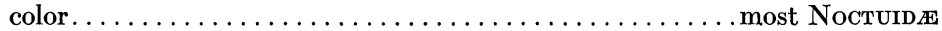

50. Fore wing with raised scale-tufts, small, with Sc and R ordinarily fused to near middle of cell but free at base ....................... NoLid $x$

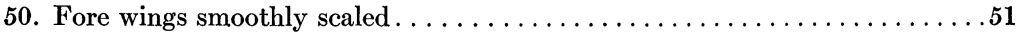

51. Sc and $\mathbf{R}$ of hind wings fused for a point about middle of cell, or connected by a cross-vein.............................most LyMantrIID

51. Sc and $\mathbf{R}$ fused from base to middle of cell. ........... most LiтноSIID

52. Legs lost, never leaving cocoon............. Psychid ( $\mathrm{s}$ in part)

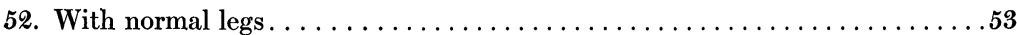

53. Cocoon seedlike, with a valve at one end (being formed of the larval case), the moth normally not leaving it............Psychid

53. Cocoon normally felted of the larval hair, or rudimentary and underground. .54

54. Abdomen closely scaled, or spined, or with bristling dark gray hair

GeOMETRID 2 (a few o $\mathrm{s}$ )

54. Abdomen smoothly clothed with fine light woolly hair; moth not normally leaving the cocoon, which is composed of the larval hair

Lymantrimde (a few $ᄋ \mathrm{~s}$ )

55. Fore wing with three or four unbranched veins only $\ldots \ldots \ldots \ldots \ldots \ldots 6$

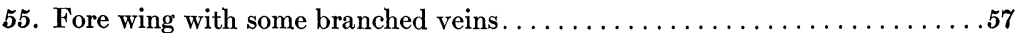

56. A large eyecap.......................... Opostegid

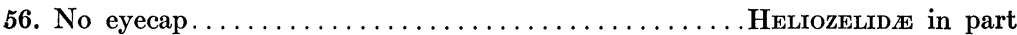

57. A well-developed eyecap, fringed with overlapping scales; labial palpi small,

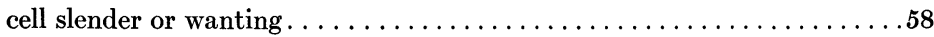

57. Eyecap not developed,- -at most with first joint of antenna large, a little hollowed on inner side, and fringed with a single row of bristles (pecten) . .59

58. Cell very small, less than a tenth area of wing, or wholly absent; membrane

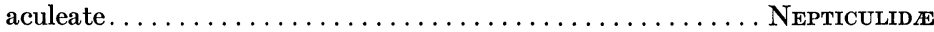

58. Cell larger, membrane not aculeate.................. Lyonetirde

59. Maxillary palpi twice as long as eye, folded, conspicuous........ Prodoxid

59. Maxillary palpi shorter than eye, or porrect.................60 
60. Vestiture of thorax of deep hair and spatulate hair, also similar on palpi and legs, the palpi usually strongly sexually dimorphic, large in both sexes; wings scaled, venation complete, with base of media preserved

TINEIDA (ANAPHORINe)

60. Palpi barely reaching middle of front or shorter, tongue absent; vestiture of thorax and tibiæ dense and hairy ............... (Cossidce in part)

60. Thorax, at least, scaled or slender, palpi also in the majority of cases, and fore and middle tibiæ; often minute moths with lanceolate wings.........61

61. Hind wing lanceolate, much narrower than its own fringe, fore wing much broader but also lanceolate........................62

61. Hind wings with well-marked anal angle and rounded or somewhat pointed apex, not strongly concave below it; when narrower than fore wings, with three well-developed anals . . . . . . . . . . . . . . . . . .

61. Hind wings various in size with produced apex, strongly concave below apex, and again produced more or less on $\mathbf{M}_{3}$ and $\mathrm{Cu}_{1}$, with well-marked anal

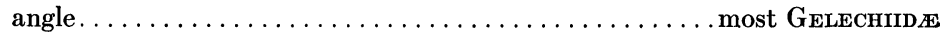

62. Maxillary palpi present and folded in repose..................63

62. Maxillary palpi obsolete, or three-jointed and porrect.............65

63. Head extremely rough, with bristling vestiture $\ldots \ldots \ldots \ldots \ldots \ldots \ldots \ldots$.

63. Head smooth-scaled, except narrowly behind............AcrolePIIDA

64. Aculeate; $R_{1}$ of hind wing much stronger than base of main stem of $R$, and appearing as a basal fork of Sc............... few Adelide

64. Not aculeate; $R_{1}$ of hind wing no stronger than basal portion of $R_{s}$, well out from base, connecting $S c$ and $R$, which are closely parallel toward base

a few Tineides

65. Head very rough and bristly on both vertex and face, second joint of palpus with lateral bristles toward tip................ TineIDes (Tenaga)

65. Lower part of face, at least, smoothly scaled; palpus without bristles.....66

66. Fore wing with four veins or less, either free or stalked, to costa from cell, and five or six veins to inner margin $\left(\mathbf{R}_{5}\right.$ running to outer margin)

some Yronomeutide

66. Fore wing with five veins to costa from cell or with only three or four to inner

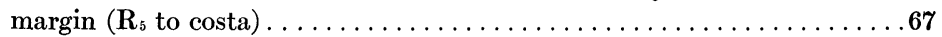

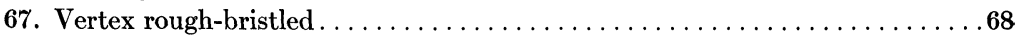

67. Vertex smooth-scaled, or with a few erect scales behind............70

68. Accessory cell very large, extending nearly half-way to base of wing, fore wing with heavy spinules on base of Sc and base of cell ........ TISCHERIID瓜

68. Accessory cell small, or more often absent; not aculeate. . . . . . . . . .69

69. A of fore wing forked at base, costa of hind wing not lobed...... BeDELLIA

69. A of fore wing perfectly simple, costa of hind wing strongly lobed, with the obscure basal parts of Sc and R closely parallel to the edge of the lobe

GracilariID无

70. Sc and $R$ of hind wing nearly straight and parallel toward base, usually connected by a distinct, but weak cross-vein $R_{1}$, a short distance out from base, in a few cases where $S c$ is very short, with $R_{1}$ independent of it, reaching the costa beyond its tip; when the costa is lobed with Sc fairly straight, and ending at the commencement of the concave portion............71 
70. Sc and $\mathbf{R}$ sharply divergent at base, $R_{1}$ when traceable appearing as a basal fork of Sc, oblique, short, and heavy, and $R$ s running nearly through the axis of the wing; or with Sc and $\mathrm{R}$ both obscure, closely parallel to the basal lobe of the costa, and $\mathbf{R}$ functionally replaced by the base of $\mathrm{M}$......72

71. Balpi upturned to vertex...................... CosmopterYGIDe

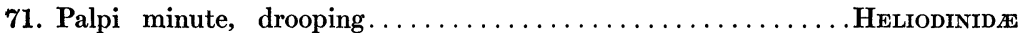

72. Maxillary palpi present, porrect...............RRACILARIID

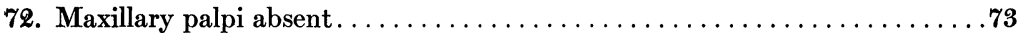

73. Cu-stem of hind wing at least two-branched, palpi usually smoothly upturned to vertex, hind tibiæ loosely hairy ................. ELACHISTID

73. $\mathrm{Cu}$-stem of hind wing simple, free, no cell, or with very short palpi . . . . .74

74. Basal joint of antenna broadened with overlapping scales (a rudiment of an eyecap), tongue weak, $\mathrm{Cu}$ of hind wing simple; hind tibia with a regular series of bristles.................. Lyonetiido (Phyllocnistis in part)

74. Basal joint simple or with a slight pecten of bristles..............75

75. Palpi if upturned not reaching middle of front, usually hanging, HeLrozelides

75. Palpi moderately long and usually slender, upturned in life

GracilariIde in part

76. $\mathrm{Cu}_{2}$ of fore wing arising less than two-thirds way out on cell, most Tortricides

76. $\mathbf{C u}_{2}$ of fore wing arising further out on cell .................

77. Wing-membrane aculeate; Sc of hind wing with a strong basal fork (the lower fork being $\mathbf{R}_{1}$ ), or considerably swollen at base, $\mathbf{R}$ and Sc usually sharply divergent from base, antennæ often extremely long, vertex very rough

ADELID in part

77. Wing-membrane not aculeate; antennæ never much longer than fore wing; $\mathbf{R}_{1}$ rarely as strong as the other veins, and when distinct separated from the base of the wing by several times its length $\ldots \ldots \ldots \ldots \ldots \ldots \ldots \ldots 78$

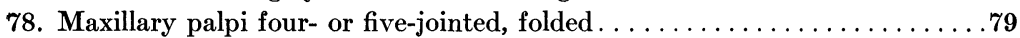

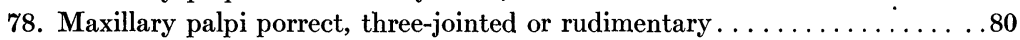

79. Head only slightly rough behind $\ldots \ldots \ldots \ldots \ldots \ldots \ldots \ldots$ ACROLEPIID $\mathbb{E}$

79. Vertex with long bristly vestiture $\ldots \ldots \ldots \ldots \ldots \ldots \ldots$ TineIDe in part

80. $M_{1}$ and ${ }_{2}$ of hind wing both absent........... Tontricides (Carposina)

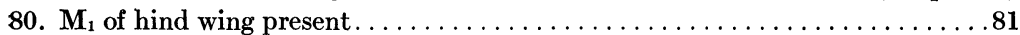

81. Labial palpi with bristles on side of second joint, or vertex and front both with extremely long rough vestiture, and second joint of palpus heavily tufted and third long; $\mathbf{R}$ and $\mathbf{M}_{1}$ of hind wing widely separate. TINeID 2 in part

81. Labial palpi without bristles, head with short, fairly smooth vestiture or third joint of palpus inconspicuous......................... 82

82. $\mathbf{R}$ and $\mathrm{M}_{1}$ of hind wing widely separate at base, at least half as far apart as at

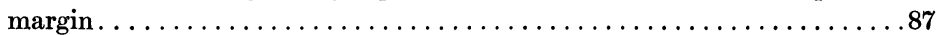

82. $R$ and $M_{1}$ of hind wing closely approximate or stalked . . . . . . . . 83

83. Palpi as long as head, with second joint triangularly scaled, and third less than half as long normally porrect. . . . . . . . . . . . . . . . . . 84

83. Palpi upturned to beyond middle of front often far beyond vertex, the third joint more than half as long as second, and upturned.............85

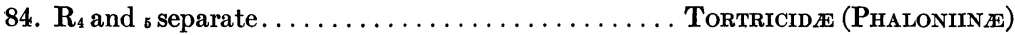

84. $\mathbf{R}_{4}$ and ${ }_{5}$ stalked, to costa.................... GeLeCHIID 2 (male Anarsia) 
85. Veins of fore wing all present and $R_{5}$ running to outer margin

YPONOMEUTIDA in part

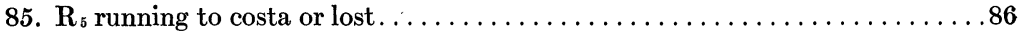

86. Fore wing with all veins from cell separately, hind wing wider, with $\mathbf{R}$ and $\mathbf{M}_{1}$

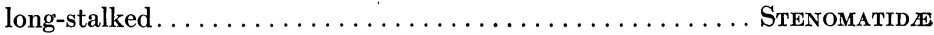

86. Fore wing with $\mathrm{R}_{4}$ and 5 stalked, the hind wing trapezoidal and usually wider, strongly rounded out at end of $\mathrm{M}_{3}$ and $\mathrm{Cu}_{1} \ldots \ldots \ldots$. few GeLECHIIDA

86. Hind wing lanceolate, narrower than fore wing......... CoSMOPTERYGIDE

87. $R_{2}$ arising at apex of cell, and $\mathrm{M}_{3}$ and cubitals also closely crowded from lower angle, male usually with strong sexual modifications; five radials run to

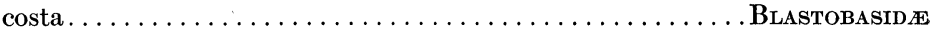

87. $R_{2}$ arising less than nine tenths the length of the cell, and well away from the

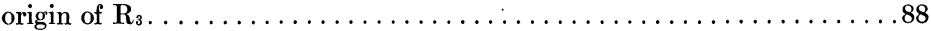

88. Five veins run from cell to costa in fore wing. . . . . . . . . . . . . . 89

88. Four veins run from cell to costa in fore wing, $\mathbf{R}_{5}$ ending decidedly below the

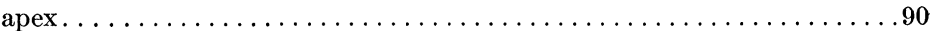

89. Hind wing with $\mathbf{M}_{2}$ arising decidedly nearer $\mathbf{M}_{1}$ than $\mathbf{M}_{3} \ldots \ldots$ ЕтнмIID

89. Hind wing with $\mathbf{M}_{2}$ arising decidedly nearer $\mathbf{M}_{3}$ than $\mathbf{M}_{1}$ or rarely half way

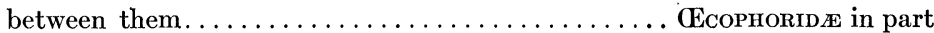

90. $R_{4}$ and ${ }_{5}$ stalked; ocelli rudimentary or absent....... WCOPHORID电 in part

90. With all veins of fore wing arising separately or (Allononyma) with $\mathbf{R}_{4}$ and s stalked and large ocelli................... YFONOMEUTID $\&$ in part

\section{EXPLANATION OF FIGURES.}

Fig. 1. Typical primitive Lepidopterous venation (Eriocephala thunbergella, with the addition, in dots, of a few veins lost in Eriocephala, but cenerally preserved), the veins numbered according to the Comstock-Needham and German systems.

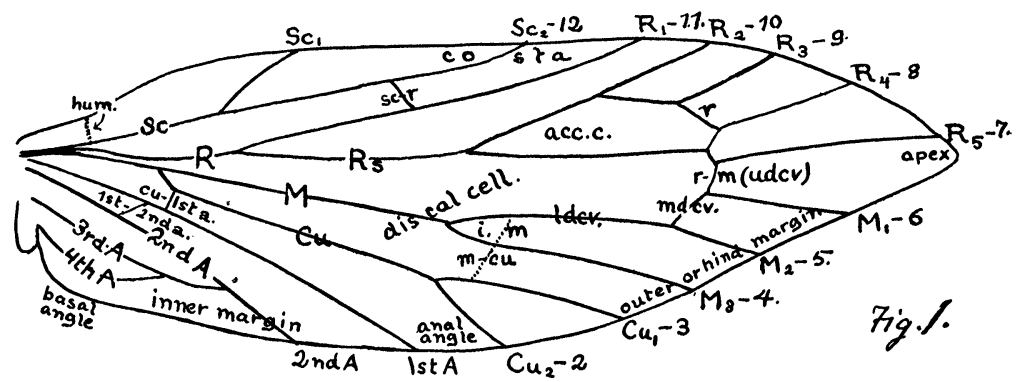

Sc, Subcosta.

R, Radius.

M, Media.

$\mathrm{Cu}$, Cubitus.

A, Anal.

hum, humeral cross-vein.

udcv, upper discocellular vein (cross-vein radius-media).

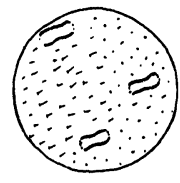


mdev, middle discocellular vein (in this case, and usually, a portion of mediaone).

ldcv, lower discocellular vein (the portion so marked is a portion of the stem of media one-plus-two, but as ordinarily defined the short cross-vein m. would also be considered part of it).

1st $\mathbf{A}$ is a concave vein, and when it becomes rudimentary is known as the submedian fold.

The veins, hum., Sc1, sc-r, r, cu-1st a, 1st-2d a, and 4th a, are lost in almost all higher forms.

i, Intercalated cell (reckoned as part of the discal cell).

acc. c, Accessory cell (reckoned as part of the discal cell in micros- and butterflies, where it is more or less completely fused with it, but not in most moths, where it is perfectly separated, when present).

Fig. 2. Portion of bleached wing-membrane, showing points of attachment of scales and aculeæ.

\section{THE ALIMENTARY CANAL OF A CERCOPID.}

\section{By J. C. Kershaw.}

The following brief notes refer to Tomaspis saccharina Dist., a pest of sugar cane in Trinidad, West Indies, where the nymphs feed on cane roots and the adults on the leaves. In the nymph of this Cercopid the air, which all sucking insects doubtless imbibe in quantity along with the liquid food, appears to pass through the alimentary canal and be utilized in forming the air-bubbles coated with mucinoid which are emitted from the anus and form the froth in which the nymph lives. After examining this Cercopid I am the more inclined to believe that (as stated in a previous paper on Flata in Psyche) the "food-reservoir" in the head of Flata functions in part as an air-separator to rid the liquid food of superabundant air before it passes through the alimentary canal. In the Cercopid nymph, however, the air is directly utilized, as mentioned above. In this Cercopid and in Cicada the diverticulum or pouch of the midgut (forming the "food-reservoir" of the head in Flata and the filter-chamber of the thorax in Cercopid and Cicada) is almost filled up by the zigzag course through it of the posterior part of the midgut and the anterior part of the malpighian tubes. This diverticulum, pouch or filter-chamber is entirely situated in the thorax, as are also the diverticula of Perkinsiella and other Homoptera mentioned in the paper referred to above; only entering the head in Flata, Pyrops and Dictyophoro- 

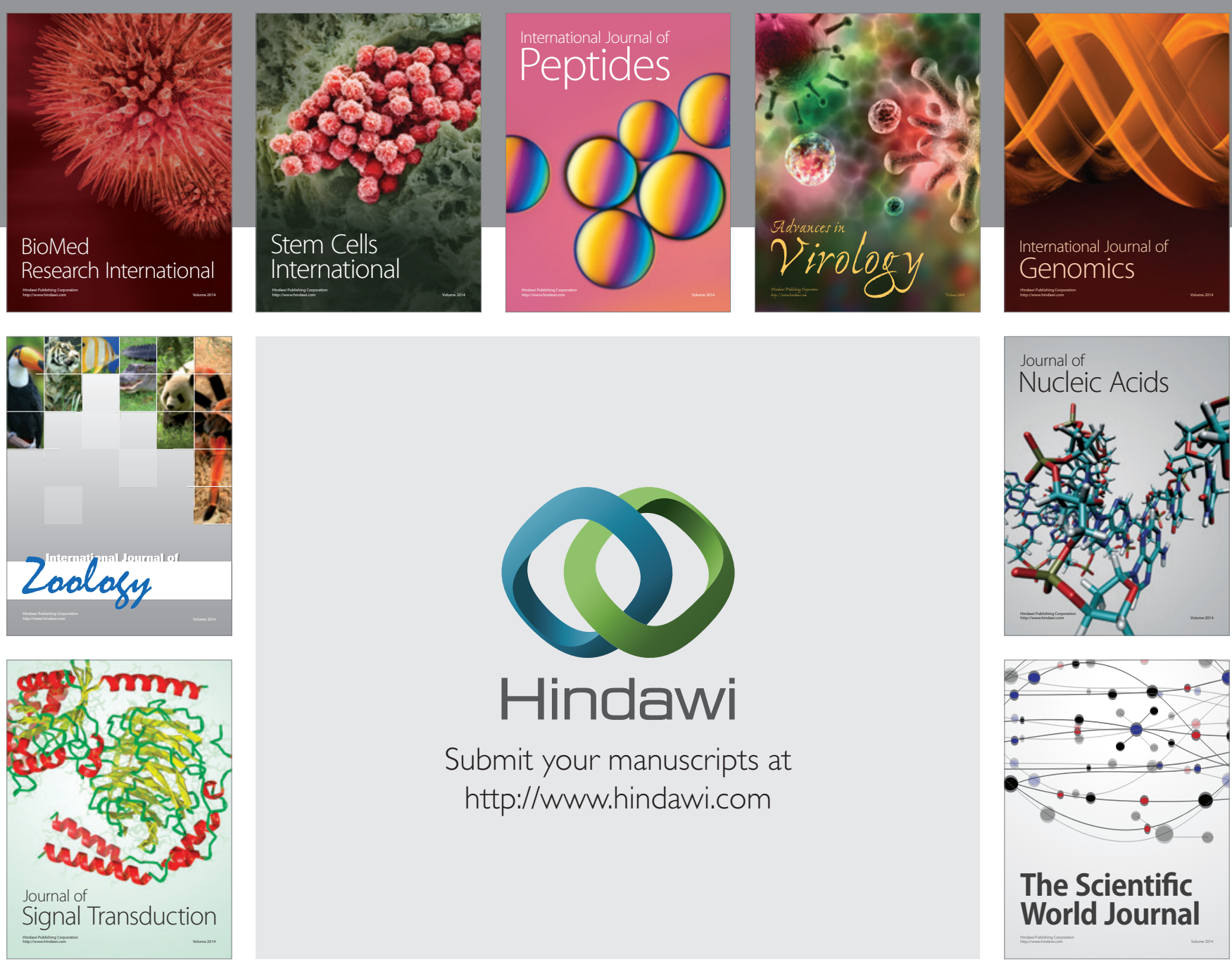

Submit your manuscripts at

http://www.hindawi.com
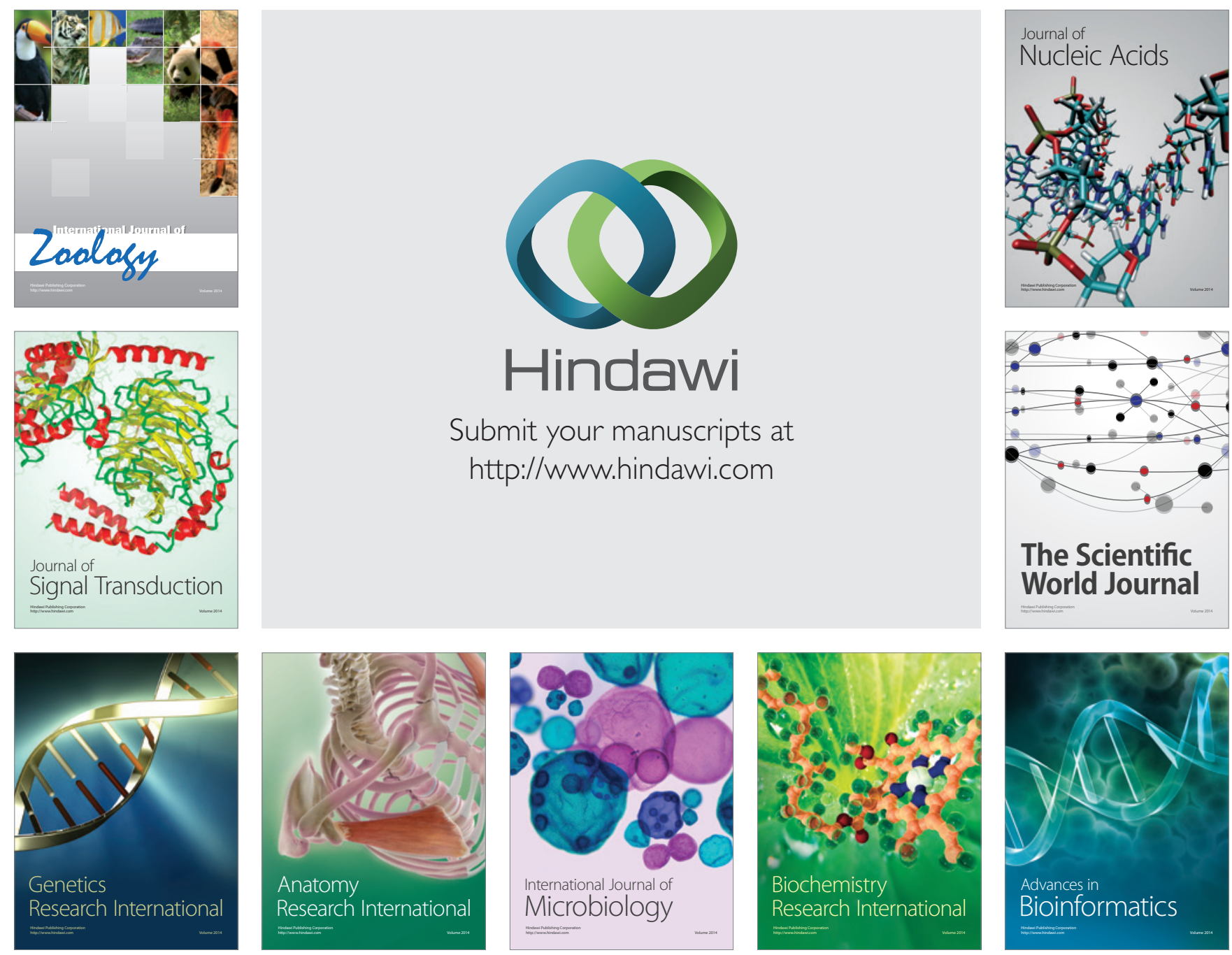

The Scientific World Journal
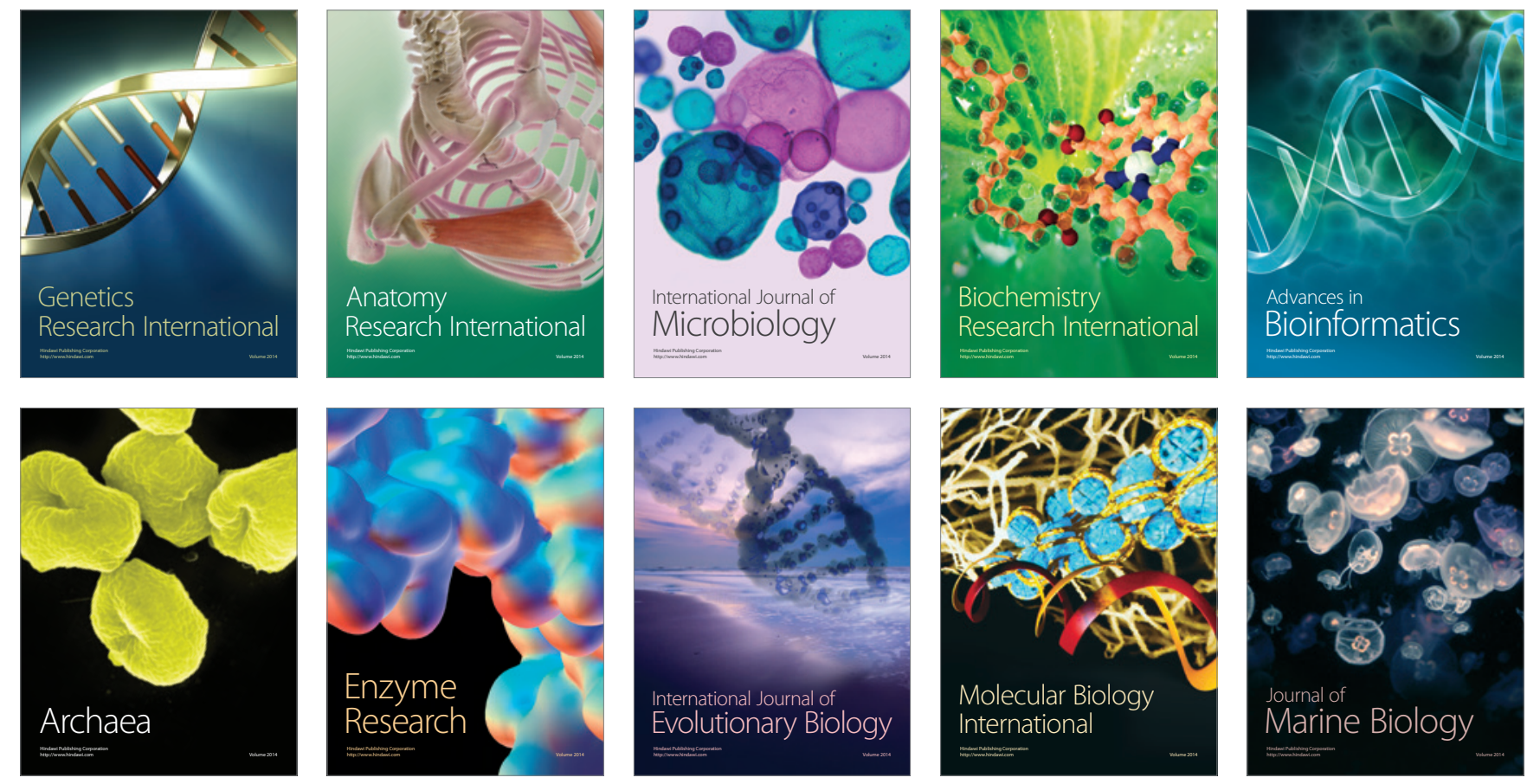